\begin{tabular}{lllll} 
ZAPISKI HISTORYCZNE & $-\underset{\text { Teszyt } 2}{\text { TOM }}$ \\
\hline
\end{tabular}

http://dx.doi.org/10.15762/ZH.2015.18

\author{
EDMUND KIZIK \\ (Instytut Historii PAN)
}

\title{
VEREIN FÜR KASCHUBISCHE VOLKSKUNDE W LATACH 1907-1914 LUDOZNAWSTWO KASZUBSKIE MIĘDZY NIEMIECKOŚCIĄ A POLSKOŚCIĄ
}

Słowa kluczowe: towarzystwo naukowe, folklor kaszubski, Prusy Zachodnie, Kaszuby

Mimo ogromnego przyrostu piśmiennictwa dotyczącego problematyki kaszubskiej mało uwagi poświęcono w nim Towarzystwu Ludoznawstwa Kaszubskiego ${ }^{1}$. Verein für kaschubische Volkskunde nie doczekał się dotychczas żadnego osobnego opracowania naukowego ${ }^{2}$. Działalność organizacji założonej przez Niemca Friedricha Lorentza (1870-1937) ${ }^{3}$ oraz Polaka Izydora Gulgowskiego (1874-1925),

${ }^{1}$ We współczesnej literaturze używa się często nazwy „Kaszubskie Towarzystwo Ludoznawcze” (m.in. Józef Borzyszkowski, Aleksander Majkowski (1876-1938). Biografia historyczna, Gdańsk-Wejherowo 2002, s. 244 nn.; i z zastrzeżeniem: Anna KwAśniewskA, Badania etnologiczne na Pomorzu Wschodnim w XIX i XX wieku. Ludzie, instytucje, osiągnięcia badawcze, Gdańsk 2009, s. 178-174). Jest ono błędne i wypacza pierwotny sens określenia „Verein für kaschubische Volkskunde”. M.in. za Magdaleną Niedzielską używam określenia Towarzystwo Ludoznawstwa Kaszubskiego, zob. Magdalena NiedzIElska, Niemieckie towarzystwa naukowe w Prusach Zachodnich w latach 1815-1920, Toruń 1993, s. 189-190.

${ }^{2}$ Artykuły Józefa Borzyszkowskiego (Kaszubskie Towarzystwo Ludoznawcze, Pomerania, 1987, nr 9, s. 10-12; Badacze i twórcy pierwszego muzeum na wolnym powietrzu, [in:] W kręu badaczy kultury Kaszub i Pomorza XIX i XX wieku, red. Józef BorzYszKowsKi, Słupsk-Gdańsk 2008, s. 88-106) są oparte na pracy: Andrzej Buкоwsкi, Regionalizm kaszubski. Ruch naukowy, literacki i kulturalny. Zarys monografii historycznej, Poznań 1950, s. 136-157. A. Kwaśniewska (Badania etnologiczne na Pomorzu Wschodnim, s. 146-154, 172-179) rekapituluje stan dotychczasowej wiedzy.

${ }^{3}$ Zob. Jadwiga ZieniukowA, Lorentz Friedrich Wilhelm, [in:] Słownik biograficzny Pomorza Nadwiślańskiego (dalej cyt. SBPN), t. 3, red. Zbigniew NowAK, Gdańsk 1997, s. 80-82; Władysław Pniewski, Życie i dzieło dra Fryderyka Lorentza, Rocznik Gdański, t. 12: 1938, s. 156-174; Józef BoRZYsZKowski, Dr. Friedrich Lorentz (1870-1937), Mecklenburger aus Güstrow, der hervorragdenste Forscher der kaschubischen Sprache, Stier und Greif. Blätter zur Kultur- und Landesgeschichte in Mecklenburg-Vorpommern, Jg. 12: 2002, s. 137-142; idem, Friedrich Lorentz wśród Kaszubów między Polska a Niemcami, [in:] Nazwy i dialekty Pomorza dawniej i dziś, t. 3, red. Róża WosIAK-ŚLIWA, Gdańsk 2000, s. 111-123.

${ }^{4}$ [Friedrich Lorentz], Izydor Gulgowski, [nekrolog], Slavia Occidentalis, t. 5: 1926, wklejka bez paginacji; Andrzej Bukowski, Gulgowski Izydor, [in:] Polski słownik biograficzny (dalej cyt. PSB), t. 9, Wrocław 1960, s. 142-144; idem, Gulgowski Izydor, [in:] SBPN, t. 2, red. Stanisław GIERSzEwsKI, Gdańsk 1994, s. 136-138; Józef Borzyszkowski, O Izydorze Gulgowskim, jego żonie Teodorze z Fethków oraz ich dokonaniach $i$ związkach $z$ młodokaszubami. Über Ernst Seefried-Gulgowski, seine Ehe- 
aż do zawieszenia spowodowanego wybuchem pierwszej wojny światowej, trwała krótko, lecz jej znaczenie dla ratowania reliktów kultury kaszubsko-pomorskiej, świadomości jej odrębności oraz tworzenia nowych form rzemiosła ludowego (haftu i garncarstwa) jest nie do przecenienia. Tym bardziej brakuje opracowań dostatecznie przybliżających formy działalności Towarzystwa, jego twórców, ich aktywności w sytuacji wzmagającego się w prowincji zachodniopruskiej napięcia narodowego. Mimo prac Anny Kwaśniewskiej ${ }^{5}$ czy Józefa Borzyszkowskiego ${ }^{6}$ i innych autorów ${ }^{7}$ wiedza o Towarzystwie zasadniczo nie wykracza poza treści zawarte w szkicu z książki Andrzeja Bukowskiego z 1950 r. ${ }^{8}$ Pozostaje ona pod tym względem nie do zastąpienia, co świadczy nie tylko o jej jakości, lecz także o problemach współczesnych badań nad kulturą kaszubską i, ogólnie, ludową Pomorza w XIX i początkach XX w.

Celem artykułu jest przynajmniej częściowe wypełnienie tej luki oraz uzupełnienie pracy A. Bukowskiego na podstawie niewykorzystanych dotychczas źródeł archiwalnych ${ }^{9} \mathrm{i}$ doniesień prasy regionalnej, przede wszystkim niemieckiej ${ }^{10}$.

frau Theodore Gulgowski-Fethke und ihren Errungenschaften und Bindungen zu Jungkaschuben, [in:] Ernst Seefried-Gulgowski [Izydor Gulgowski], Von einem unbekannten Volke in Deutschland. Ein Beitrag zur Volks- und Landeskunde der Kaschubei. O nieznanym ludzie w Niemczech. Przyczynek do ludoznawstwa i krajoznawstwa Kaszub, tłum. Magdalena Darska-Łogin, red. Józef BorzyszKOwSKI, Berlin 1911 - Gdańsk 2012 [dwujęzyczna edycja pierwodruku z 1911 r.], s. XVII-CXXXV. Szkoda, że skądinąd wartościowa edycja nie została zaopatrzona w aparat krytyczny. Utrudnia to śledzenie kontekstów i odniesień autorskich zarówno Heinricha Sohnreya (wstęp), jak i I. Gulgowskiego (zasadnicza treść książki).

${ }^{5}$ A. KwaśniewsKa, Badania etnologiczne na Pomorzu Wschodnim, s. 172-179; eadem, Instytut Bałtycki $i$ jego rola $w$ etnografii Kaszub w okresie dwudziestolecia międzywojennego, [in:] Badania kaszuboznawcze w XX wieku, red. Józef Borzyszkowski, Cezary OBRaCht-Prondzyński, Gdańsk 2001, s. 43-55.

${ }^{6} \mathrm{~J}$. BorzYszkowski, O Izydorze Gulgowskim, s. V-CXXXV.

${ }^{7} \mathrm{~W}$ innym świetle przedstawia problemy tych osobowości: Hans-Jürgen BömeLBURG, Grenzüberschreitende kaschubische Biographien mit schmaler zeitgenössischer Resonanz: Gulgowski, Lorentz und Majkowski. Nationale und interkulturelle Ursachen, [in:] Grenzüberschreitende Biographien zwischen Ost- und Mitteleuropa. Wirkung-Interaktion-Rezeption, hrsg. v. Tobias Weger, Frankfurt am Main 2009, s. 255-283.

${ }^{8}$ A. Buкоwsкi, Regionalizm kaszubski, s. 136-157. Zob. Antoni KaKareкo, Z prac nad spuściznq Andrzeja Bukowskiego w Bibliotece Głównej Uniwersytetu Gdańskiego. Kolekcje warsztatowe dotyczące Hieronima Derdowskiego, Izydora Gulgowskiego, ks. Leona Heyke, Jana Karnowskiego, Władysława Pniewskiego i Franciszka Sędzickiego, Acta Cassubiana, t. 3: 2001, s. 181-182 (Gulgowski); Angelika DąBal, Antoni Kakareko, Z prac nad spuścizna Andrzeja Bukowskiego w Bibliotece Głównej Uniwersytetu Gdańskiego, ibid., t. 6: 2004, s. 190-191 (Lorentz).

${ }^{9}$ Zespół gdańskiego Kunstverein oraz materiały zgromadzone w jednostkach pt. „Akta dotyczące kaszubskiej wystawy ludowej, lata 1909-1914”, oraz „Akta wystawy kaszubskiej, lata 1909-1910”: Archiwum Państwowe w Gdańsku (dalej cyt. APGd.), sygn. 361/125; 361/129. Materiały przeoczyła A. Kwaśniewska: „W APG brak jest wielu materiałów źródłowych dotyczących tego towarzystwa” (eadem, Badania etnologiczne na Pomorzu Wschodnim, s. 173, przyp. 131).

${ }^{10}$ Prasa niemiecka pozwala zrozumieć zróżnicowany stosunek opinii publicznej do rozwoju środowisk badaczy ludowości kaszubskiej i ruchu młodokaszubskiego. Niestety rozpoznanie gdańskiej i zachodniopruskiej prasy niemieckiej sprzed 1914 r. pozostaje dezyderatem badawczym. Zob. ważny przegląd źródłoznawczy: Prasa gdańska na przestrzeni wieków, red. Marek ANDRZEJEWski, Gdańsk 1999. 
Friedrich Wilhelm Lorentz po studiach germanistycznych i językoznawczych w Heidelbergu i Lipsku, uzyskaniu doktoratu (1894) oraz nieudanych próbach rozpoczęcia kariery akademickiej uzyskał prywatne stypendium umożliwiające mu przeprowadzenie gruntownych badań językoznawczych wśród Słowińców i tzw. Kabatków. Pierwsze wyniki prac opublikował w latach 1903-1905 w Petersburgu. Gdy osiadł jako nauczyciel w Kartuzach w 1904 r., był już w pełni ukształtowanym i uznanym w świecie nauki badaczem mowy kaszubskiej. Inną drogę przebył młodszy wiekiem Izydor Gulgowski, również nauczyciel, lecz po prowincjonalnej szkole zawodowej, który po ukończeniu seminarium nauczycielskiego w Tucholi w 1898 r. objął posadę w szkole we Wdzydzach. Tam, wspólnie z poślubioną w 1899 r. Agatą Teodorą Fethke-Gulgowską (1860-1951) ${ }^{11}$, również poświęcił się zbieraniu zabytków rękodzieła kaszubskiego oraz pracy organicznej na rzecz podniesienia poziomu kultury życia tamtejszej ludności. W odkupionym w 1906 r. zabytkowym domu ${ }^{12}$ małżonkowie urządzili kolekcję kaszubskich i pomorskich zabytków rękodzieła ludowego ${ }^{13}$, co dało początek późniejszemu muzeum ${ }^{14}$. I. Gulgowski był na tym polu autodydaktykiem pozostającym pod wpływem idei płynących ze środowisk społeczników i ludoznawców niemieckich, przede wszystkim kontrowersyjnego z uwagi na późniejsze związki z nazistami Heinricha Sohnreya (1859-1948) ${ }^{15}$. H. Sohnrey cieszył się powszechnym uznaniem zarówno Niemców, jak i Polaków. Był również uważany za mentora I. Gulgowskiego. W pochodzącej z 1929 r. opinii Jana Karnowskiego H. Sohnrey „otworzył haftom kaszubskim drogę na świat. Spopularyzował je w swoich pismach i zachęcał do pokazywania

${ }^{11}$ Andrzej Buкоwski, Gulgowska Teodora, [in:] PSB, t. 9, s. 142-143; idem, Gulgowska Teodora, [in:] SBPN, t. 2, s. 135-136.

${ }^{12} \mathrm{Na}$ temat domu zakupionego przez I. Gulgowskiego zob. notę: Bernhard ScHmid, Ankauf eines kassubischen Bauernhauses, Die Denkmalpflege in der Provinz Westpreußen im Jahre 1906, 4. Bericht, Danzig 1907, s. 9-10; Izydor Gulgowski, Das Bauernhaus in der Kaschubei, Mitteilungen des Vereins für kaschubische Volkskunde (dalej cyt. Mitteilungen), Bd. 1, Leipzig 1910, s. 88, 98. I. Gulgowski uzyskał na zakup zasiłek władz kościerskich w wysokości 900 marek. Po 1918 r. przemilczał ten fakt, zob. A. KwaśniewsKa, Badania etnologiczne na Pomorzu Wschodnim, s. 152-153.

${ }^{13} \mathrm{O}$ historii ruchu ochrony zabytków ludowych na terenie Niemiec zob. artykuły w pracy zbiorowej: Antimodernismus und Reform. Zur Geschichte der deutschen Heimatbewegung, hrsg. v. Edeltraud Klueting, Darmstadt 1991; Werner Hartung, Konservative Zivilisationskritik und regionale Identität. Am Beispiel der niedersächsischen Heimatbewegung 1895 bis 1919, Hannover 1991.

${ }^{14}$ Tadeusz SADKowski, Dzieło Gulgowskich we Wdzydzach. U źródeł polskiego muzealnictwa etnograficznego na wolnym powietrzu, [in:] Muzea pomorskie - twórcy, zbiory i funkcje kulturowe. VIII Konferencja Kaszubsko-Pomorska, Słupsk, red. Cezary OBRACHT-Prondzyński, Słupsk-Gdańsk 2005, s. 234-245. Nie odmawiając I. Gulgowskim zasług i prekursorstwa, należy jednak sprostować pojawiającą się wielokrotnie nieścisłą informację, że Wdzydze stanowią pierwszą tego rodzaju instytucję na terenach Rzeszy. Wcześniej powstało muzeum w Husum (1899).

${ }^{15}$ Zob. idee H. Sohnreya na tle epoki: Georg STöcкER, Agrarideologie und Sozialreform im Deutschen Kaiserreich. Heinrich Sohnrey und der Deutsche Verein für ländliche Wohlfahrts- und Heimatpflege 1896-1914, Göttingen 2011; oraz mało krytyczna: Gerd Busse, Zwischen Hütte und Schloss. Heinrich Sohnrey. Schriftsteller, Sozialreformer, Volkskundler. Mit ausgewählten Beispielen aus seinem literarischen Werk, Holzmünden 2009, s. 70-74 (zdjęcia H. Sohnreya z okresu podróży na Kaszuby w 1911 i 1912 r.). 
na wystawach"16. Gdy powstała cytowana opinia, H. Sohnrey - jako typowy przedstawiciel ideologii „Blut und Boden” - popierał już ruch narodowosocjalistyczny. W październiku 1933 r. z 88 pisarzami niemieckimi podpisał sławny adres do Adolfa Hitlera, a w jego powieściach pojawiły się akcenty rasistowskie ${ }^{17}$.

Nie wiadomo nic bliższego o początkach współpracy F.W. Lorentza i I. Gulgowskiego oraz wykluwania się idei powołania wspólnej organizacji ludoznawczej, w której można było połączyć różne formy zainteresowań kaszubszczyzną ${ }^{18}$. Ich działalność można rozpatrywać zarówno na tle rozwoju ruchu naukowego i wyodrębnienia się ludoznawstwa w dyscyplinę akademicką (etnografia i etnologia) ${ }^{19}$, jak i wysiłków na rzecz określenia prawnych podstaw ochrony krajobrazu kulturowego i naturalnego w Niemczech ${ }^{20}$. Zarówno F.W. Lorentz, jak i I. Gulgowski w roku 1907, w momencie powołania Towarzystwa, byli ludźmi stosunkowo młodymi. F.W. Lerentz miał 37 lat, I. Gulgowski - 33. Działalność Towarzystwa przypadła na najlepsze lata jego twórców, również najaktywniejszych członków. To na ich barkach spoczywała większość prac zarówno organizacyjnych, jak i działalność naukowa, publicystyczna i popularyzatorska. Pozostałe osoby z zarządu takiej aktywności nie przejawiały, lecz dbały o niezbędne zaplecze również finansowe i organizacyjne służące pracy F.W. Lorentza i I. Gulgowskiego ${ }^{21}$.

${ }^{16}$ Jan Karnowski, Syn borów (Ś.p. Izydor Gulgowski), Mestwin. Dodatek naukowo-literacki do Słowa Pomorskiego, 1929, nr 5, s. 3-4. Zob. Tadeusz Pietry коwski, Prof. Henryk Sohnrey, znakomity ludoznawca niemiecki i jego stosunek do Kaszub, ibid., 1929, nr 9, s. 1-3; pierwszą stronę reprodukuje: J. BorzyszKowski, O Izydorze Gulgowskim, s. XLVII. Na temat J. Karnowskiego zob. podstawową pracę: Cezary OвRAcht-Prondzyński, Jan Karnowski (1886-1939) - pisarz, polityk i kaszubsko-pomorski działacz regionalny, Gdańsk 1999.

${ }^{17}$ Nieporozumieniem jest stwierdzenie J. Borzyszkowskiego (idem, O Izydorze Gulgowskim, s. XLVI, XLIX), że „Jego [H. Sohnreya - E.K.] działalność dyskredytowana nieco w okresie nazizmu, zyskała - tak za życia, jak i po śmierci - powszechne niemal uznanie, czego wyrazem było nadanie mu w I połowie lat trzydziestych honorowego obywatelstwa Fredelsloh, Götttingen i Jühnde”. Obywatelstwem tych miast został uhonorowany przez hitlerowców. Zob. na ten temat: Frank MöвUs, "In Sachen Heinrich Sohnrey". Gutachten zur nationalsozialistischen Vergangenheit des "Solling-Dichters”, Göttingen 2011.

${ }^{18}$ Józef Bonzyszkowski, Teodora i Izydor Gulgowscy - badacze i twórcy pierwszego muzeum na wolnym powietrzu, [in:] idem, Antropologia Kaszub i Pomorza. Badania - kultura - zycie codzienne, Gdańsk 2010, s. 109.

19 Trudny do zastąpienia jest starszy zarys: Dzieje folklorystyki polskiej 1864-1918, red. Helena KAPEŁuś, Julian KRzYŻanowski, Warszawa 1982. Dla Niemiec od przełomu XIX i XX w. do 1945 r. zob.: Christoph Daxelmüller, Vorwort [dodany do wydania faksymile], [in:] Handwörterbuch des deutschen Aberglaubens, hrsg. v. Hanns BÄchtold-StäUbli unter Mitwirkung v. Eduard HoffMANN-KraYer, Bd. 1, Berlin 2000 (faksymile wydania: Bd. 1, Berlin-Leipzig 1927), s. $1^{\star}-64^{\star}$.

${ }^{20}$ Felix Hammer, Die geschichtliche Entwicklung des Denkmalrechts in Deutschland, Tübingen 1995, s. 131 (rozporządzenia z lat 1902-1914); Winfried SpeItKamp, Die Verwaltung der Geschichte. Denkmalpflege und Staat in Deutschland 1871-1933, Göttingen 1996 (praca podstawowa z doskonałym przeglądem literatury).

${ }^{21}$ I. Gulgowski korzystał z fotografii udostępnianych mu m.in. przez kolegów z zarządu Towarzystwa, np. landrata Trüstedta czy też inspektora szkolnego Paschkego z Tczewa. 


\section{ZAŁOŻENIE I STATUT}

Towarzystwo zostało powołane na spotkaniu założycielskim w Kartuzach 21 IX 1907 r. $^{22}$, w czasie którego przyjęto statut. Z powodu nieścisłości formalnych uzupełniono go miesiąc później (21 października). Statut, opublikowany w kartuskiej oficynie Ottona Ehlersa ${ }^{23}$, rozesłano członkom z pierwszym numerem biuletynu informacyjnego i listą członków na 30 I $1908 \mathrm{r}^{24}$

Statut Towarzystwa w ośmiu punktach i 28 paragrafach wskazywał i charakteryzował: 1) cele działalności; 2) zakres planowanych prac; 3) siedzibę, charakter umocowania prawnego i cykl sprawozdawczy; 4) członkostwo; 5) zarząd Towarzystwa oraz inne organy statutowe; 6) komisje robocze i specjalne; 7) zebranie walne, porządek obradowania; 8) sposoby zmiany statutu i rozwiązanie Towarzystwa. Towarzystwo zostało zarejestrowane w kartuskim sądzie w rejestrze związków i organizacji - „eingetragener Verein”; „e.V” (wpisowe wyniosło 6,75 marki), na ogólnych zasadach prawnych (Bürgerliches Gesetzbuch - BGB $\S \S 21-89^{25}$ ). Treść statutu, poza celami szczegółowymi, nie odbiegała od innych podobnych dokumentów dla stowarzyszeń społeczno-naukowych ${ }^{26}$. Siedzibą Towarzystwa były Kartuzy, miejsce pracy i zamieszkania F.W. Lorentza i sporej liczby członków. Organizacja nie dysponowała stałym lokalem, sekretariat znajdował się w domu I. Gulgowskiego we Wdzydzach, a zebrania członków - zwykłe i walne - organizowano $\mathrm{w}$ hallu miejscowego kartuskiego hotelu Hassego (dzisiejszy budynek Miejskiej i Powiatowej Biblioteki Publicznej). Było to również miejsce publicznych odczytów oraz wystaw.

${ }^{22}$ A. Bukowski, Regionalizm kaszubski, s. 145.

${ }^{23}$ Verein für Kaschubische Volkskunde. Satzungen (Beschlossen in den Versammlungen am 21. September und 21. November 1907), Karthaus 1907, druk w: APGd., sygn. 361/129, s. 84-87; zmiany w statucie z 11 XI 1908 r., druk w: ibid., s. 88-89. Fragmenty statutu związku cytuje: A. BukowskI, Regionalizm kaszubski, s. 146-147.

${ }^{24}$ Verein für kaschubische Volkskunde. Vereinsnachrichten, Nr. 1, hrsg. v. dem Schriftführer des Vereins I. Gulgowski in Sanddorf bei Alt Bukowitz (dalej cyt. Vereinsnachrichten), [Karthaus] 1908 (bez paginacji, numeracja archiwalna) w: APGd., sygn. 361/129, s. 92-95; faksymile: J. Borzyszkowski, O Izydorze Gulgowskim, s. XXX-XXXI. A. Bukowski miał do dyspozycji „Vereinsnachrichten" nr 3 i 5 oraz spis członków ze stycznia 1914 r., zob. A. Buкowski, Regionalizm kaszubski, s. 147, przyp. 48. Zbiór druków znajduje się w APGd.: Vereinsnachrichten, Nr. 1 (styczeń 1908 r.) - APGd., sygn. 361/129, s. 92-95; Vereinsnachrichten, Nr. 3 (listopad 1908 r.) - ibid., s. 96-103; Vereinsnachrichten, Nr. 4 (wrzesień 1909 r.) - ibid., s. 81-82; Vereisnachrichten, Nr. 5 (listopad 1909 r.) - ibid., s. 104-111; Vereinsnachrichten, Nr. 6 (wrzesień 1910 r.) - ibid., s. 254-255 (niestety s. 255 jest sklejona z kopertą, co zasłania nazwiska członków z 9 miejscowości); Vereinsnachrichten, Nr. 7 (listopad 1911 r.) - ibid., sygn. 361/125, s. 104-107; Vereinsnachrichten, Nr. 8 (czerwiec 1912 r.) - ibid., s. 115-123; druk: Verein für Kaschubische Volkskunde. Mitglieder Verzeichniß (styczeń 1914 r.) - ibid., s. 130-133; inny zbiór druków, zob. Verein für Kaschubische Volkskunde - Biblioteka Gdańska PAN, sygn. Oc 1453 8, tam również: Vereinsnachrichten, Nr. 2 (wrzesień 1908 r.).

${ }^{25}$ Hans Delius, Deutsches Vereinsrecht und Versammlungsrecht in privat- und öffentlich-rechtlicher Beziehung unter besonderer Berücksichtigung des preussischen Rechts, Berlin 1908 (wyd. 4).

${ }^{26}$ M. NiEDZIELSKA, op.cit., s. 190-191. 
Cele Towarzystwa sformułowano krótko: „I, § 1: Der «Verein für kaschubische Volkskunde» hat den Zweck, alles auf die kaschubische Volkskunde im weitesten Umfange bezügliche Material zu sammeln und der Wissenschaft und der Allgemeinheit zugänglich zu machen".

Wiedzę o zgromadzonych przejawach ludowości kaszubskiej, celem ich udostępnienia nauce i ogółowi, miano publikować na łamach czasopisma „Mitteilungen des Vereins für kaschubische Volkskunde”. W ramach dostępnych środków zamierzano wspierać różnego rodzaju prace badawcze nad ludoznawstwem kaszubskim (I, § 2). Językiem czasopisma ustanowiono niemiecki, teksty źródłowe zamierzano publikować w języku oryginału $\mathrm{z}$ ich niemieckim tłumaczeniem. Ustalono zasadę apolityczności publikacji, wykluczając drukowanie opinii o charakterze politycznym, religijnym lub społeczno-ideologicznym (I, § 3 ).

Rok sprawozdawczy Towarzystwa w związku z datą wpisu na sądową listę ustanowiono na 1 października (III, § 4). Zwykłymi członkami Towarzystwa mogły być tak osoby fizyczne, jak i prawne. Składka roczna wynosiła 3 marki; jednorazowa wpłata 30 marek zwalniała od opłat członkowskich na zawsze. Członków honorowych zwalniano od opłat z zachowaniem pełni praw. Za nieuiszczanie składek można było utracić członkostwo (IV, § 6-8). Częściej jednak starano się o uiszczenie zaległości, jak np. w przypadku gdańskiego Kunstverein, który w 1914 r. zalegał $\mathrm{z}$ wpłatami za trzy lata ${ }^{27}$. W zamian członkowie otrzymywali bezpłatnie drukowany biuletyn Związku („Vereinsnachrichten”) oraz wydawnictwa z rabatem. Redagowany przez I. Gulgowskiego biuletyn zawierał informacje o działalności Towarzystwa, rozliczenia finansowe oraz listy członków. Druki rozsyłano po zebraniach walnych, sprawozdawczych i nadzwyczajnych.

Zarząd Towarzystwa składał się z siedmiu osób: przewodniczącego, jego zastępcy, sekretarza i zastępcy, skarbnika oraz dwóch członków. Byli oni wybierani przez zwykłe zgromadzenie członków na trzyletnią kadencję. Pierwszy zarząd składał się w większości z osób zamieszkałych w Kartuzach: dr. F.W. Lorentza (przewodniczący), jego zastępcy Altmanna, powiatowego inspektora szkolnego; sekretarzem był I. Gulgowski z Wdzydz, zastępcą sekretarza Drajewski (Kartuzy); skarbnikiem - Palm, powiatowy inspektor szkolny (Kartuzy). Funkcje członków zarządu pełnili landrat kościerski Friedrich Trüstedt oraz lekarz dr Bruski (Kartuzy $)^{28}$. Po ustąpieniu $z$ funkcji F.W. Lorentza przewodniczącym Towarzystwa jesienią 1909 r. został Anastazy Kopaczewski (1873-1916), ksiądz z podkartuskiego Goręczyna, w Towarzystwie obecny od $1908 \mathrm{r}^{29}$ Mimo trudności ${ }^{30}$ utrzymał on jedność organizacji, którą kierował aż do zawieszenia jej działalności w $1914 \mathrm{r}$. Członkami ostatniego zarządu w 1914 r., poza ks. Kopaczewskim, byli Bahr, weterynarz z Kartuz, I. Gulgowski jako sekretarz, a jego zastępcą był L. Borkowski

\footnotetext{
${ }^{27}$ Notatka z 17 IV 1914 r., APGd., sygn. 361/125, s. 135; zob. ibid., s. 136.

${ }^{28}$ Vereinsnachrichten, Nr. 1.

${ }^{29}$ Sławomir Decowski, Kopaczewski Anastazy, [in:] SBPN, t. 2, s. 442-443.

${ }^{30}$ M. NiedZielsKa, op.cit., s. 190.
} 
z Grzybowa. Funkcję skarbnika pełnił kupiec Lipczinski (Kartuzy). Członkami byli także landrat Trüstedt, drukarz Ehlers, dr Bruski, Pleus, przewodniczący gminy (Kartuzy) oraz miejscowy kartuski architekt Max Neumann.

Zebrania walne wymagały ogłoszenia $\mathrm{w}$ „Karthauser Kreisblatt” na dwa tygodnie przed planowanym dniem zebrania (Statut, VI, § 21). W zwykłych spotkaniach sprawozdawczych nie brało udziału zbyt wielu członków, np. na spotkaniu zamykającym pierwszy rok działalności (30 IX 1908 r.) obecnych było 15 członków oraz, jako gość, wybitny botanik - prof. Hugo Conwentz z Gdańska ${ }^{31}$.

Statut Towarzystwa po wpisaniu do rejestru (7 lipca) dwukrotnie zmieniano ${ }^{32}$. Po raz pierwszy dokonano tego na nadzwyczajnym zebraniu 11 XI 1908 r. Uzupełnieniu uległ $\S 2$, albowiem do celów Towarzystwa poza wydawaniem czasopisma włączono jeszcze organizację publicznych wykładów oraz zakładanie zbiorów specjalnych zabytków twórczości ludowej, zdjęć oraz publikacji z zakresu problematyki regionalnej i innej związanej z celami statutowymi ${ }^{33}$. Istotne było ustanowienie porządku działania biblioteki Towarzystwa (Bibliotheksordnung) ${ }^{34}$. Pozostałe zmiany nie miały, jak się wydaje, większego znaczenia. Powtórnej zmiany statutu dokonano na walnym zebraniu członków 30 IX 1909 r. ${ }^{35}$ Stało się to pod naciskiem dyskusji politycznej, która rozpętała się w związku z ponawianymi atakami politycznymi na różne przejawy prac naukowych na rzecz Kaszub. Z uwagi na kompleksowy charakter tego zagadnienia i jego konsekwencje omówię je w dalszej części.

\section{CZŁONKOWIE TOWARZYSTWA}

Tab. 1. Członkowie Verein für kaschubische Volkskunde w latach 1907-1914

\begin{tabular}{|l|c|c|}
\hline \multicolumn{1}{|c|}{ Rok, miesiąc } & liczba członków & w tym osoby prawne \\
1907 (21 września) & 86 & 8 \\
1908 (1 listopada) & $187^{\mathrm{a}}$ & 11 \\
1909 (1 listopada) & 222 & 11 \\
1910 (31 sierpnia) & $269^{\mathrm{b}}$ & 9 \\
1914 (1 stycznia) & 188 & 10 \\
\hline
\end{tabular}

Uwaga: od 1909 r. publikowano nie pełną liczbę członków, lecz jedynie nowo przyjętych do Towarzystwa.

Źródło: Vereinsnachrichten, Nr. 1-8, [Karthaus] 1908-1912; Mitgliederverzeichnis, [Karthaus] 1914.

a Stan na 1 października to 182 osoby, zob. Vereinsnachrichte, Nr. 3, s. 8.

b Według: Danziger Allgemeine Zeitung z 27 IX 1910 r.

${ }^{31}$ Vereinsnachrichten, Nr. 3.

${ }^{32}$ Ibid., Nr. 2.

${ }^{33}$ Druk: Verein für kaschubische Volkskunde. Aenderungen in den Satzungen, Karthaus [1909] - APGd., sygn. 361/129, s. 88-89.

${ }^{34}$ Druk: Verein für kaschubische Volkskunde. Bibliotheksordnung, Karthaus [1909] (pozyskiwanie zbiorów, wypożyczanie, odpłatności za korzystanie itp.) - APGd., sygn. 361/129, s. 90-91.

${ }^{35}$ A. Bukowski, Regionalizm kaszubski, s. 148. 
W pierwszym roku działalności największą grupę członków stanowili nauczyciele (w tym również inspektorzy szkolni i dyrektorzy szkół), których było 37, czyli bez mała połowa. Inne spore grupy to urzędnicy lokalnej administracji państwowej i samorządowej oraz duchowni z rejencji gdańskiej i kwidzyńskiej, kupcy, przedsiębiorcy, lekarze oraz nieliczni ziemianie. Większość członków pochodziła z Kartuz (26), 15 było z Gdańska i Sopotu, 13 z Kościerzyny. Członkami prawnymi były m.in. lokalna komórka Deutscher Ostmarkenverein ze Starej Kiszewy ${ }^{36}$, ale i Biblioteka Miejska w Gdańsku, Bibliotek Ludowa w Tczewie, Towarzystwo Oświaty Ludowej w Sopocie (Gesellschaft für Volksbildung), a nawet sopockie Stowarzyszenie Ochrony Konsumentów (Konsumenten-Schutz Verband). Z ważniejszych osób wymienić należy: dr. Aleksandra Majkowskiego (1876-1938) ${ }^{37}$ zamieszkałego ówcześnie w Kościerzynie, działacza społecznego i późniejszego współtwórcę ruchu młodokaszubskiego; Ottona Ernsta Blecha (1846-1922), pastora i archidiakona kościoła św. Katarzyny w Gdańsku, autora prac z historii Gdańska; dr. Jakuba Glassa (1864-1942), pochodzącego z Mazur, wybitnego prawnika i badacza dziejów Kościoła ewangelickiego w Polsce. Na pierwszej liście widniał również zamieszkały w Poznaniu ks. dr Władysław Łęgowski (1877-1941), działacz społeczny zainteresowany badaniami etnograficznymi. Prominentnymi członkami byli m.in. Bernhard Schmid (1872-1947), prowincjonalny konserwator zabytków w Prusach Zachodnich, jeden $\mathrm{z}$ najwybitniejszych znawców zagadnienia, podejmujący również kwestie drewnianego budownictwa wiejskiego na Pomorzu; Aleksiej Szachmatow (1864-1920), profesor Uniwersytetu w Petersburgu, językoznawca i wybitny historyk kultury słowiańskiej i wczesnoruskiej. Obecność na liście zamieszkałego w Sopocie Diederta von Dembowskiego, redaktora liberalnego „Danziger Neueste Nachrichten”, dawała gwarancję upowszechnienia informacji o działalności ludoznawczej na łamach tej największej lokalnej gazety. Na pierwszej liście wymieniono również bliżej nieznane kobiety. Możliwe, że należały one do kręgu przyjaciółek Teodory, żony I. Gulgowskiego. Sama T. Gulgowska członkinią Towarzystwa nie była. W listopadzie 1909 r. członkostwo uzyskała feministka i egzaltowana pisarka Marcelina Kulikowska (1872-1910), stało się to pod wrażeniem wycieczki na Kaszuby ${ }^{38}$.

Przegląd kolejnych list z nowymi członkami dobitnie świadczy o sukcesie organizacji, której udało się pozyskać dość powszechnie miejscowe środowiska nauczycielskie, ale i przekroczyć granice regionalne. Chociaż była traktowana jako organizacja niemiecka, to zrzeszała wielu miejscowych Polaków i Kaszubów. Często zresztą dopiero późniejsze wybory decydowały o ostatecznej przynależności

${ }^{36} \mathrm{Z}$ Kościerzyny pochodził również pastor Joseph Paul Harder, aktywny członek Hakaty. W Prusach Zachodnich działało 44 kół Związku.

${ }^{37}$ J. Borzyszkowski, Aleksander Majkowski, s. 249. A. Majkowski początkowo był dość aktywnym członkiem Towarzystwa. W ramach prac Towarzystwa wygłosił referat publiczny (31 III 1909 r.) w Kościerzynie.

${ }^{38}$ Vereinsnachrichten, Nr. 5, s. 8. Zob. Marcelina KulıкowsKa, Z wędrówek po kraju, Kraków 1911, s. 17-43; o I. Gulgowskim, F.W. Lorentzu i Towarzystwie ludoznawczym - ibid., s. 37. 
narodowej. Poza członkami - osobami prawnymi, jak np. władze samorządowe - akces do Towarzystwa zgłosił gdański Kunstverein - Towarzystwo Sztuk Pięknych (od 1909 r.). Na zasadzie wzajemności do Kunstverein wstąpiła żona I. Gulgowskiego, zamiłowana malarka ${ }^{39}$.

Lista członków w ciągu kolejnych lat ulegała dość dynamicznym zmianom: część osób skreślano za niepłacenie składek, niektórzy sami rezygnowali z powodu wyjazdu lub różnic ideowych. Na pierwszej liście wśród członków wymieniono zarówno kościerskie koło Ostmarkenverein, którym kierował pastor ewangelicki Joseph Harder, jak i późniejszego wydawcę „Gryfa”, wspomnianego A. Majkowskiego. Ten ostatni widnieje jeszcze na liście z listopada 1909 r. ${ }^{40}$ Obydwaj (Niemiec J. Harder i Polak A. Majkowski) ostatecznie zrezygnowali z członkostwa w Towarzystwie, zdystansowali się wobec celów i metod ludoznawców, a następnie przeprowadzali publiczną krytykę Verein für kaschubische Volkskunde.

\section{FINANSE TOWARZYSTWA}

Zarząd miał do dyspozycji niewielkie środki; w roku finansowym 1908/1909 było to 1073 marki (mk) i 38 fenigów (fen.). Najważniejszym źródłem dochodów były składki członkowskie, w tymże roku finansowym zgromadzono $z$ tego tytułu 682,20 mk, zasiłek z Zarządu Muzeów Zachodniopruskich (Verwaltung der Westpreußischen Provinzial-Museen) wyniósł $200 \mathrm{mk}$, sprzedaż pisma - 81,35 mk, wpływy ze sprzedaży biletów na wykłady - 84,10 mk; odsetki od wkładu dały - 4,16 mk. Corocznie przyznawana pomoc Zarządu Muzeów Zachodniopruskich (po raz ostatni przyznana w 1914 r.) umożliwiała wydawanie pisma. Wydanie dwóch zeszytów czasopisma w 1908/1909 r. to wydatek 332,42 mk, druk „Vereinsnachrichten" - 57,50 mk; pozostałe druki (formularze, koperty z nadrukami), ogłoszenia w prasie kosztowały 74,50 mk. Koszty zbierania informacji do zbioru nazw miejscowych (Flurnamensammlung) - $57 \mathrm{mk}$, działalność biblioteki to jedynie 3,90 mk, a koszty organizacji wykładów (wynajęcie sal, audioskopu do przeźroczy), koszty zarządzania poczty etc. $-143,32 \mathrm{mk}$. Saldo na rok 1909/1910 to 165 mk i 74 fen., przy wpływach 1073,38 mk i rozchodach w wysokości 907,64 mk. Jak na tak niewielkie środowisko były to całkiem dobre wyniki. Np. atakujące kaszubskich ludoznawców gdańskie koło Ostmarkenverein liczące w 1910 r. aż 1075 członków dysponowało budżetem w wysokości raptem $2573 \mathrm{mk}^{41}$. Członkowie zarządu działali społecznie. I. Gulgowski przy okazji sprawozdania finansowego z 1908/1909 r. nie bez dumy podkreślił oddanie swoje i innych pracy naukowej ${ }^{42}$. Gdy z początkiem lipca 1912 r. I. Gulgowski w związku ze stanem zdrowia prze-

${ }^{39}$ Izydor Gulgowski do Ernsta Goeritza, Wdzydze, 29 X 1909 r., APGd., sygn. 361/125, s. 190-193 .

${ }^{40}$ Vereinsnachrichten, Nr. 5, s. 5.

${ }^{41}$ Die Ortsgruppe Danzig des Deutschen Ostmarkenvereins, Danziger Allgemeine Zeitung z 14 III 1911 r., s. 7; Danziger Zeitung, Jg. 53: 1911, Nr. 124 z 14 III 1911 r. (wydanie wieczorne).

${ }^{42}$ Vereinsnachrichten, Nr. 5, s. 2. 
szedł $\mathrm{w}$ stan spoczynku ${ }^{43}$, to pewne dochody poza publicystyką zapewniały mu funkcje sołtysa i sekretarza gminy wdzydzkiej ${ }^{44}$.

\section{FORMY DZIAŁALNOŚCI TOWARZYSTWA}

Najbardziej spektakularnym sukcesem było uruchomienie czasopisma naukowego „Mitteilungen des Vereins für kaschubische Volkskunde" w nim artykuły analityczne, wyniki badań terenowych oraz rejestrację zabytków. Wydanie czasopisma powierzono lipskiej oficynie Ottona Harrassowitza. Już w styczniu 1908 r. ukazał się pierwszy 32-stronnicowy (dwa arkusze) zeszyt z artykułami F.W. Lorentza i I. Gulgowskiego, w którym w krótkim wstępie w sześciu punktach wyłożono cele wydawcó ${ }^{46}$. Zwrócono w nim uwagę na stan zachowania zabytków, m.in. całkowity już zanik ubiorów ludowych, prosząc o przekazywanie zabytków Towarzystwu: „Bemerkenswerte Volkstrachten bestehen wohl gegenwärtig nirgends. Die Leute haben aber ihre besondere Volkstracht gehabt. Die Überreste sind zu sammeln und den Verein zu überweisen" ${ }^{37}$.

Zeszyt rozesłano bezpłatnie w celach reklamowych i wymiany. Do 1913 r. ukazały się dwa tomy zawierające osiem zeszytów (t. 1, ss. 232; t. 2, ss. 160). W latach 1908-1910 wydawano po dwa zeszyty rocznie. Zeszyt piąty, który ukazał się w początkach 1910 r., zamknął tom pierwszy cyklu. Paginacja zeszytów w obrębie rocznika była ciągła; zeszyty miały spisy treści; po zamknięciu tomu dodawano łączny spis treści. Nie jest znana wysokość nakładu - zapewne nie przekraczała 200 egzemplarzy. Pod koniec 1910 r. ukazał się pierwszy zeszyt tomu drugiego; w 1911 r. z powodu zamieszania politycznego oraz zmian w zarządzie (ustąpienie F.W. Lorentza z funkcji przewodniczącego i współwydawcy, zaangażowanie I. Gulgowskiego w inne przedsięwzięcia) $)^{48}$ nie ukazał się żaden z zeszytów. Po opanowaniu kryzysu, w latach 1912 i 1913, Towarzystwo wydało jeszcze po jednym zeszycie; tom drugi zawierał jedynie trzy zeszyty (dwa ostatnie liczyły po dwa arkusze), zredagowane przez I. Gulgowskiego (,im Auftrag des Verein harausgegeben von I. Gulgowski - Sanddorf”). Na osłabienie aktywności wpłynęło założenie przez A. Majkowskiego „Gryfa”, konkurencyjnego polskiego czasopisma. Łączyło ono zagadnienia ludoznawcze z polityczno-społecznymi i przejęło część środowiska autorskiego (np. K. Nitscha; publikował tam również F.W. Lorentz), tworząc również alternatywne formy zbieractwa oraz rejestracji zabytków ludowych. I. Gulgowski

${ }^{43}$ A. Buкоwsкi, Regionalizm kaszubski, s. 152.

${ }^{44} \mathrm{~J}$. BorZYszKowsKI, O Izydorze Gulgowskim, s. LIX.

${ }^{45}$ Współczesna recepcja czasopisma jest ograniczona. Pominięto je np. w przeglądzie zagadnienia czasopiśmiennictwa pomorskiego, zob. Mariusz WoŁos, Główne kierunki rozwoju czasopiśmiennictwa historycznego na Pomorzu Nadwiślańskim w XIX i XX wieku, Zapiski Historyczne, t. 63: 1998, z. 2, s. 85-117.

${ }^{46}$ Równocześnie jednak dodano: „Die Kaschuben hatten auch eine Volkskunst. Bemalte Truhen, Schränke, Stühle, Bettgestelle, Wiegen, Tongeschirre finden sich noch zahlreich in den Hütten” (Was wir wollen?, Mitteilungen, Bd. 1, s. 7).

${ }^{47}$ Ibid., s. 7.

${ }^{48}$ Vereinsnachrichten, Nr. 7, s. 3. 
nie dysponował takimi kontaktami w świecie nauki jak jego poprzednik, a dotychczasowi autorzy opróżnili swoje szuflady i nie byli w stanie dostarczyć nowych tekstów na dostatecznie wysokim poziomie. W ostatnich zeszytach publikowano referaty wygłoszone na spotkaniach ludoznawców (B. Schmida, O.E. Blecha). Do ciekawszych obok artykułu B. Schmida ${ }^{49}$ należał również niewielki tekst samego I. Gulgowskiego poświęcony kilku zabytkom sztuki ludowej ${ }^{50}$. Po opublikowaniu zeszytu ósmego w 1913 r. wydawanie pisma zawieszono. Nie było ono w stanie na siebie zarobić, zwracając w najlepszym razie jedynie trzecią część wyłożonych środków. Cena poszczególnych zeszytów czasopisma była zróżnicowana. Pierwszy, liczący 36 stron, kosztował 70 fen., następne kosztowały już więcej: zeszyt drugi - 1,20 mk, zeszyt trzeci - $1 \mathrm{mk}$, zeszyt czwarty $-1,50 \mathrm{mk}$, a zeszyt piąty $-3,10$ mk. Dla porównania pierwszy zeszyt fatalnie wydrukowanego „Gryfa” z listopada 1908 r. o objętości dwóch arkuszy wydawniczych kosztował 50 fen. Wydane dwa tomy stały na wysokim poziomie edytorskim oraz technicznym. Oddzielono część z rozprawami naukowymi od zawierającej przyczynki źródłowe; osobnym działem były omówienia i recenzje publikacji. Większe artykuły były z reguły publikowane w częściach w kolejnych zeszytach. Autorami tekstów byli przede wszystkim F.W. Lorentz (zabytki językoznawcze), I. Gulgowski (zabytki kultury materialnej, pieśni z zapisami nutowymi) oraz Jan A. Patock (1886-1940) ${ }^{51}$, publikujący przypowieści, bajki, zagadki, pieśni i przysłowia. Niekiedy zdarzały się większe teksty innych członków, np. Kazimierza Nitscha, którego artykuł z polskiego rękopisu przetłumaczył na niemiecki F.W. Lorentz ${ }^{52}$. Nie brakowało niewielkich drobiazgów autorstwa osób bez większego obycia z działalnością naukową, jak. np. kupca Maxa Pintusa $^{53}$ na temat przysłów i zwyczajów Chmielna.

$\mathrm{W}$ porównaniu z innymi regionalnymi periodykami ludoznawczymi z obszaru Niemiec, np. pomorskiego „Blätter für pommersche Volkskunde” (Szczecin, od 1893 r.), śląskiego „Mitteilungen der Schlesischen Gesellschaft für Volkskunde” (Wrocław, od 1896 r.), nie sposób nie zauważyć, że wśród wielu tekstów o wysokim poziomie merytorycznych nie brakuje tekstów słabszych, lecz i tak pismo broni się swoją wyjątkowością. Tekstom towarzyszyły fotografie, rysunki, co było ewidentnym sukcesem wydawniczym redaktorów pisma. Ważna jest rejestracja zabytków, nawet gdy ich opis formalny musi wzbudzać pewne wątpliwości. Nie ma tu miejsca nawet na opis bibliograficzny artykułów, nie wspominając o ich recepcji

${ }^{49}$ Bernhard Schmid, Über ältere Holzbauten in der Kaschubei, Mitteilungen, Bd. 2, 1912, s. 65-75 .

${ }^{50}$ Isidor Gulgowski, Beiträge zur Volkskunst in der Kaschubei, ibid., s. 78-90.

${ }^{51}$ Jerzy SAMP, Patock, Jan Andrzej, [in:] SBPN, t. 3, s. 394-395.

${ }^{52}$ Kazimierz Nitsch, Reichte das Kaschubei einst weiter nach Süden?, Mitteilungen, Bd. 1, s. 191$-194$.

${ }^{53}$ J. Borzyszkowski, Aleksander Majkowski, s. 250-251. M. Pintus należał do kartuskiej gminy żydowskiej. Jego córka Else przeżyła okupację w ukryciu, zob. Else-Elżbieta PINTus, Meine wahren Erlebnisse. Moje prawdziwe przeżycia, opr. Józef Borzyszkowski, tłum. Mirosława BorzyszkowSKA-SZEWCZYK, Gdańsk 2005, s. 17. 
badawczej. Krytyczna ocena należy do specjalistów (językoznawców, etnologów, historyków, historyków sztuki, muzeologów, regionalistów). Przystępując do takiej oceny, należy zdawać sobie sprawę z tego, że czasopismo działało na terenie o słabym zapleczu intelektualnym: wychodziło w Kartuzach, liczących w 1900 r. nieco ponad 2,5 tysiąca mieszkańców. Rejencja gdańska dopiero dzięki powstaniu w 1904 r. gdańskiej Technische Hochschule doczekała się ośrodka akademickiego z prawdziwego zdarzenia. Pismo jednak weszło do obiegu naukowego i zostało odnotowane na łamach innych periodyków naukowych ${ }^{54}$. Zamieszczone tam teksty zostały wykorzystane m.in. przez autorów Handwörterbuch des deutschen Aberglaubens $(1927-1942)^{55}$.

W 1909 r. powołano komisję mającą na celu zbieranie materiałów do nazewnictwa nazw terenowych (Arbeitsauschuss für die Sammlung der Flurnamen) ${ }^{56}$ oraz do zorganizowania wystawy sztuki kaszubskiej. W ramach przygotowań I. Gulgowski nawiązał kontakt z gdańskim Kunstverein, proponując wystawienie kaszubskiej ceramiki. Jednak okazało się, że nie można takiej znaleźć. Przewodniczący Kunstverein Ernst Goeritz zaprosił do współpracy znanego malarza Bertolda Hellingratha (1877-1954) oraz dr. Hermanna Phlepsa (1877-1964) - znawcę sztuki ludowej z gdańskiej Technische Hochschule. B. Hellingrath m.in. na podstawie haftów z nadesłanych mu czepków ze zbiorów I. Gulgowskiego opracował wzory graficzne, które przedstawiono latem 1909 r. mistrzowi garncarskiemu Fryderykowi Neclowi z Chmielna. W grudniu 1909 r. pierwsze gotowe partie zdobionych wyrobów ceramicznych F. Necla trafiły na rynek gdański ${ }^{57}$, powtarzając wcześniejszy sukces komercyjny wdzydzkich haftów ${ }^{58}$. Dzięki zachowanej korespondencji znane są nie tylko okoliczności, w jakich doszło do powstania nowokaszubskiej ceramiki Neclów, ale nawet jaka była liczba, asortyment oraz cena pierwszej partii garnków i talerzy ${ }^{59}$.

Mniej znana jest praca T. Gulgowskiej, która nie włączyła się bezpośrednio w prace Towarzystwa, poświęcając czas propagowaniu chałupnictwa ludowego. Nawiązała ona m.in. kontakty $\mathrm{z}$ kierowanym przez Käthe Zimmer, żonę pastora z Nowej Cerkwi, zrzeszeniem popierającym rękodzieło kobiece (Verband der

\footnotetext{
${ }^{54} \mathrm{~Np}$. nota w kronice naukowej w: Zeitschrift für Volkskunde, Jg. 19: 1909, s. 210.

${ }^{55}$ Handwörterbuch des deutschen Aberglaubens, Bd. 1-10, Berlin-Leipzig 1927-1942 (faksymile: Berlin 2000). Praca m.in. z uwagi na obciążenie naciskami politycznymi jest kontrowersyjna, zob. komentarze: Ch. DAXelmülleR, op.cit., s. $20^{\star}-42^{*}$.

${ }^{56}$ Anruf zur Sammlung der Flurnamen, Mitteilungen, Bd. 1, s. 81-86, tam również opracowane dokładnie formularze dla zbieraczy.

${ }^{57}$ Wyroby trafiły do Ottona Sablewskiego, zajmującego się handlem dziełami sztuki, zob. list: Ernst Goertz do Maxa Pintusa, Gdańsk-Wrzeszcz, 8 XII 1909 r., APGd., sygn. 361/129, s. 205-206.

${ }^{58}$ Zagadnienie opracowałem osobno, zob. Edmund Kızıк, Kontakty Izydora Gulgowskiego z gdańskim Kunstverein w latach 1909-1910. U źródeł ceramiki nowokaszubskiej, Kwartalnik Historii Kultury Materialnej [w druku].

${ }^{59}$ Wycena Necla (Noetzel) ze specyfikacją dostawy, zob. pismo M. Pintusa, Chmielno, 14 XII 1909 r., APGd., sygn. 361/129, s. 208-209, 211-213.
} 
Westpreußische Landwirtschaftliche Hausfrauenverband) ${ }^{60}$. Aktywność i sukcesy T. Gulgowskiej budziły uznanie i wzmacniały pozycję jej męża; również towarzyszyły działalności samego Towarzystwa.

Niestety planowana na 1910 r. ekspozycja kaszubska w refektarzu klasztornym w Kartuzach, mimo uzyskania wsparcia finansowego, nie doszła do skutku. Rzekomo nie udało się zebrać dostatecznej liczby obiektów ${ }^{61}$, o czym doniosła wrześniowa prasa ${ }^{62}$. Jednak to nie brak eksponatów zadecydował o odłożeniu inicjatywy, tych bowiem miał I. Gulgowski pod dostatkiem, lecz raczej kryzys w działalności Towarzystwa wywołany krytyką płynącą zarówno ze strony środowisk hakatystów, jak i młodokaszubów. Dopiero w dniach od 23 do 30 VI 1912 r. w hotelu Hassego w Kartuzach zorganizowano wystawę wyrobów chałupniczych „Ausstellung für Hausfleiss und Volkskunst in der Kaschubei", ukazującą techniki plecenia, tkania, wyplatania z korzeni sosnowych oraz garncarstwa. Bilet wstępu na wystawę kosztował 50 fen., uczniowie płacili połowę; członkowie Towarzystwa mieli wstęp bezpłatny $^{63}$. Wystawie zapowiadanej również $\mathrm{w}$ prasie gdańskiej ${ }^{64}$ towarzyszył tekst autorstwa I. Gulgowskiego zawierający najistotniejsze zagadnienia podnoszone we wcześniejszych publikacjach poświęconych sztuce ludowej i rękodziełu na Kaszubach: Hausfleiss und Volkskunst in der Kaschubei ${ }^{65}$.

Ludoznawcy z Kartuz oraz I. i T. Gulgowscy nie byli już jedynymi, którzy zajmowali się w tym czasie kolekcjonerstwem kaszubskim. Dołączył do nich A. Majkowski, który wcześniej, bo w roku 1911 (od 25 czerwca do 23 lipca), zorganizował własną prezentację w kościerskim „Bazarze”.6. Rękodzieła kaszubskiego nie było na wystawie zbyt wiele. Chociaż przeważały monety oraz inne zabytki mające podkreślić związki Pomorza z Polską, to najważniejszy był efekt propagandowy i pierwszeństwo przed „ludoznawcami niemieckimi” z Towarzystwa. Na łamach redagowanego „Gryfa” w specjalnym numerze ukazał się okolicznościowy prze-

${ }^{60}$ Ogólnie: Anke Sawahn, Die Frauenlobby vom Land. Die Landfrauenbewegung in Deutschland und ihre Funktionärinnen 1898 bis 1948, Frankfurt am Main 2009 (niestety bez informacji o T. Gulgowskiej-Fethke).

${ }^{61}$ Ibid. Według noty z „Danziger Neuesten Nachrichten” (z 8 VIII 1910 r.) wystawa miała mieć charakter sezonowy od maja do września. Tam również informacje o składzie komisji powołanej $\mathrm{w}$ tej sprawie.

${ }^{62} \mathrm{O}$ niepowodzeniu przedsięwzięcia zob. Danziger Allgemeine Zeitung z 28 IX $1910 \mathrm{r}$.

${ }^{63}$ Vereinsnachrichten, Nr. 7 z artykułem-przewodnikiem: [Isidor GULGOwsKI], Hausfleiss und Volkskunst in der Kaschubei.

${ }^{64}$ Ausstellung für Volkskunst und Hausfleiss in der Kaschubei, Danziger Zeitung, Jg. 54: 1912, Nr. 275 z 14 VI 1912 r. (wydanie wieczorne). Na poniedziałek zapowiedziany został wykład I. Gulgowskiego pt. „Die volkswirtschaftliche Bedeutung der Hausindustrie unter besonderer Berücksichtigung seiner persöhnliche Erfahrungen”.

${ }^{65} \mathrm{Ibid}$.

${ }^{66}$ Zob. Przewodnik po wystawie ludoznawczej w Kościerzynie, Poznań 1911; J. Bonzyszkowski, Aleksander Majkowski, s. 294-296; idem, O Izydorze Gulgowskim, s. XLIII. Inne wystawy odnotowuje: A. Buкоwsкi, Regionalizm kaszubski, s. 139. Wątpliwe, aby, jak pisze J. Borzyszkowski (idem, O Izydorze Gulgowskim, s. XLIII), przy organizacji wystawy nawiązano współpracę z „Niemcem” I. Gulgowskim. Wśród osób wspomagających nie wspomina się jego osoby. 
wodnik po wystawionych eksponatach ${ }^{67}$, a zbiory stały się zalążkiem muzeum kaszubskiego w Sopocie ${ }^{68}$.

Spotkania członków Towarzystwa po części sprawozdawczej i udzielenia absolutorium zarządowi kończyły się wysłuchaniem wieczornych wykładów publicznych. Na podstawie „Vereinsnachrichten” wiadomo, że pierwszy publiczny wykład wygłosił 21 X 1907 r. pastor Otto Blech z Gdańska, który mówił o „dawnych dziejach Pomorza”. W „Wiadomościach Towarzystwa” podkreślono, że słowa pastora O. Blecha wywołały długą i ożywioną dyskusję („An den Vortrag schloss sich ein längerer Meinungsaustausch") ${ }^{69}$. Kolejnymi referentami byli: 4 II 1908 w Kościerzynie: I. Gulgowski, „Starokoszubska sztuka ludowa”; 17 marca F.W. Lorentz - „Starsza literatura kaszubska”, oraz bez wymienienia tytułów wystąpień 21 i 29 X 1909 r. ${ }^{70}$ (Paschke w Wejherowie i F.W. Lorentz w Lęborku); 6 i 31 marca (Friedrich w Bytowie, A. Majkowski 31 marca w Kartuzach). Informacje o zebraniach z wykładami były zamieszczane w prasie codziennej ${ }^{71}$. Odczyty były imprezami płatnymi: członkowie płacili 25 fen., inni 50 fen. Organizowano również objazdowe, odpłatne wykłady publiczne; zwykle połączone z prezentacją przeźroczy. Towarzystwo prowadziło również badania ratownicze, na rzecz zachowania dawnego charakteru zabudowy oraz tradycyjnych technik w budownictwie wiejskim. W związku z nowymi przepisami budowlanymi zakazującymi używania słomy i trzciny do krycia dachów zaangażowano się w 1908 r. w akcję pisania petycji do władz prowincjonalnych. Mimo poparcia władz miejscowych oraz akcji publicystycznej ${ }^{72}$ przedsięwzięcie nie zakończyło się powodzeniem ${ }^{73}$. Zarząd Towarzystwa był otwarty na nowe formy gromadzenia informacji, np. postanowiono o zbieraniu fotografii z Kaszub. Początkiem kolekcji stał się dar drukarza kartuskiego Ehlersa, który ofiarował 47 fotografii z widokami Kartuz i okolic.

\section{KRYTYKA DZIAŁALNOŚCI}

Poza środowiskami uczonych czy inteligenckich kręgów entuzjastów chłopskości i ludowości działalność Verein für kaschubische Volkskunde nie mogła liczyć na obiektywną ocenę współczesnych polityków. Cele etnografów wpadły między koła młyńskie nowoczesnych ruchów narodowych, które na nowo zdefiniowaną

${ }^{67}$ Przewodnik po wystawie ludoznawczej kaszubsko-pomorskiej w Kościerzynie w 1911 roku od 25 czerwca do 23 lipca, Gryf, R. 3: 1911, nr 6 (osobny numer); [Aleksander MAJKоwsкI], Wystawa ludoznawcza kaszubsko-pomorska w Kościerzynie, ibid., nr 4-5, s. 153-156; J. BoRzYszKowsKI, Aleksander Majkowski, s. 293-295.

${ }^{68}$ J. Borzyszkowski, Aleksander Majkowski, s. 394-395, faksymile Ustawy Towarzystwa Muzeum Kaszubsko-Pomorskiego w Sopocie (15 IX 1913 r.); A. KwAśNIEwsKA, Badania etnologiczne na Pomorzu Wschodnim, s. 204-206.

${ }^{69}$ Vereinsnachrichten, Nr. 1.

${ }^{70}$ Danziger Neueste Nachrichten, Nr. 231 z 2 X 1909 r. (wycinek w: APGd., sygn. 361/129, s. 128).

${ }^{71}$ Danziger Neueste Nachrichten, Nr. 79 z 3 IV 1911 r., załącznik 3.

${ }^{72}$ Isidor Gulgowski, Schutz den Ströhdächern, Heimat und Welt. Mittwochs-Unterhaltungsbeilage der Danziger Zeitung z 28 VII 1909 r., s. 117-118.

${ }^{73}$ Vereinsnachrichten, Nr. 5, s. 2-3; na temat odmowy nadprezydenta prowincji z 17 V 1909 r. 
ludowość podporządkowały dążeniom narodowotwórczym i państwotwórczym. Dlatego działania F.W. Lorentza i I. Gulgowskiego były krytykowane zarówno przez środowiska związane z lokalnymi kołami Ostmarkenverein, jak i zwolenników ruchu młodokaszubskiego. Ci ostatni odseparowali się od naukowego ruchu ludoznawczego, formułując przede wszystkim cele polityczne.

Krytyków ze strony niemieckiej łączyła zarówno irytacja bezpośrednio związana z sukcesami pracy organicznikowskiej I. i T. Gulgowskich, jak i rozgłosem wokół badań nad kaszubskością jako taką. O ile Towarzystwu odmawiano naukowości, o tyle Kaszubom już jakiejkolwiek godnej uwagi kultury ${ }^{74}$. W naukowym zdefiniowaniu odrębności kaszubskiej (mowy, tradycji) upatrywano motywów sprzyjających mąceniu w głowie maluczkich, co w efekcie popychało ich do związków z polskością. Oskarżenia trwały od wielu miesięcy. W berlińskiej „Allgemeine Zeitung" ze stycznia 1910 r. ukazała się korespondencja z Gdańska zatytułowana Das Polentum in der nördlichen Kaschubei ${ }^{75}$. Jej autor wyraził zaniepokojenie z powodu opublikowania broszury przedstawiającej polskim gościom kurortu położenie lokalnej polskiej lub polsko-kaszubskiej społeczności. Wymienił ,jungkaschubische Bewegung" i wspomniał o tym, że zysk ze sprzedaży tej broszury będzie przeznaczony na naukę dzieci kaszubskich w języku polskim. Namacalnym dowodem nasilenia propolskiej działalności politycznej było powstanie „Gryfa”, który również poza ludoznawstwem stał się przede wszystkim platformą polityczną ruchu Młodych Kaszubów. Ataki trwały przez kilka miesięcy ${ }^{76}$, prowadząc ostatecznie do rezolucji w tej sprawie podjętej przez członków gdańskiego Ostmarkenverein $\mathrm{w}$ sprawozdaniu rocznym organizacji w sierpniu $1910 \mathrm{r} .{ }^{77}$

Ataki zmusiły zarząd Towarzystwa do zajęcia stanowiska w tej sprawie. Doszło do tego w czasie dorocznego walnego spotkania w Kartuzach 26 IX 1910 r. W punkcie pierwszym miano przedyskutować środki przeciwko tego rodzaju oskarżeniom: „Maßnahmen gegen die seitens der Geschäftstelle Danzig des Ostmarkenvereins ausgetreten Verdächtigungen des Vereins"78. Według relacji prasowej F.W. Lorentz ustosunkował się do pojawiających się oskarżeń („Leider sei noch die Meinung verbreitet, daß der Verein sich in dem Dienste einer politischen Partei stellen könnte"). Zebrani zdecydowanie oddalili oskarżenia gdańskiego koła hakatystów ${ }^{79}$.

${ }^{74}$ A. Bukowski, Regionalizm kaszubski, s. 147-149.

${ }^{75}$ Allgemeine Zeitung, Nr. 22 z 27 I 1910 r.

${ }^{76}$ Zob. O zadaniach i celach ruchu młodokaszubskiego, Gryf, R. 2: 1910, nr 6, s. 187-188 (w związku ze streszczeniem referatu opublikowanego w: Danziger Neueste Nachrichten, Nr. 135 z 13 VI 1910 r.).

${ }^{77}$ Sprawozdanie w: Danziger Allgemeine Zeitung, Nr. 180 z 5 VIII 1910 r.; komentarz polski: Germanizatorzy a ruch kaszubski, Gryf, R. 2: 1910, nr 8, s. 228-229.

${ }^{78}$ Vereinsnachrichten, Nr. 6.

79 „Der Verein nimmt mit Verwunderung Kenntnis von dem von der Geschäftsstelle Danzig des deutschen Ostmarkenvereins herausgegebenen Jahresbericht erklärt die darin enthaltenem Verdächtigung, daß der Verein die jungkassubischen Bewegung in ihren Bestrebungen unterstutz habe, für irrig, und muß dieße Kritik, als auf Unnkentniß beruhrend, energisch zurückwießen”, Danziger Neueste Nachrichten, Nr. 227 z 28 IX 1910 r., dział: „Vereine, Versammlungen”. Podobnie w: Danzi- 
W czasie spotkania landrat Hagemann zaproponował, aby na łamach czasopisma recenzować pisma tylko wtedy, gdy dotyczą one bezpośrednio problematyki statutowej Towarzystwa. Przedsięwzięte środki nie wpłynęły na uspokojenie sytuacji, zresztą nie mogły, albowiem krytycy winą za działanie młodokaszubów obciążali przede wszystkim ludoznawców.

Na zintensyfikowanie debaty wpłynęła dyskusja wokół książki I. Gulgowskiego. Na przełomie 1910 i 1911 r. w berlińskim wydawnictwie H. Sohnreya ukazały się dwie prace I. Gulgowskiego: Von einem unbekannten Volke in Deutschland ${ }^{80}$ oraz broszura Ländlicher Hausfleiß in der Kaschubei ${ }^{81}$. Obydwie prace stanowiły zebranie doświadczeń z prac ludoznawczych i wspólnych wysiłków małżonków I. i T. Gulgowskich mających na celu ocalenie starych oraz tworzenie nowych form kultury regionalnej. W obydwu widoczny jest wpływ ideowy środowiska H. Sohnreya. Pierwsza z prac (Von einem unbekannten Volke in Deutschland) wywołała dodatkowo burzę polityczną, którą dość skrupulatnie relacjonowała ówczesna prasa ${ }^{82}$. Nie tyle z powodu treści pracy. Z politycznego punktu wiedzenia istotniejszy był poprzedzający ideowy wstęp, do napisania którego I. Gulgowski pozyskał H. Sohnreya ${ }^{83}$. H. Sohnrey, który w związku z pracami swego towarzystwa od 1896 r. wielokrotnie odwiedzał Prusy Zachodnie ${ }^{84}$, również Kaszuby ${ }^{85}$, bywał także we Wdzydzach ${ }^{86}$. Berliński działacz w pracy małżeństwa I. i T. Gulgowskich widział potwierdzenie swoich poglądów. Uważał, że jedynie dochodowa praca na wsi pozwoli zatrzymać we wschodnich prowincjach odpływ ludności do miast („Landflucht”), co według niego wpływało na wzmocnienie elementu słowiańskiego ${ }^{87}$. Miasto w jego kon-

ger Allgemeine Zeitung z 27 IX 1910 r.: „,[Dr. F.W. Lorentz] wies die von verschiedenen Seiten aufgestellten Behauptungen züruck, daß der Verein polnische Bestrebungen verfolgte". Komentarz polski: Zwycięstwo hakatyzmu nad nauka, Gryf, R. 2: 1910, nr 10, s. 289-294.

${ }^{80}$ Ernst Seefried-GulgowsKi, Von einem unbekannten Volke in Deutschland. Ein Beitrag zur Volks- und Landeskunde der Kaschubei, Berlin 1911 (wyd. 2: Berlin 1913); recenzja: Stanisław Kujot, Zapiski Towarzystwa Naukowego w Toruniu (dalej cyt. Zapiski TNT), t. 2: 1911, z. 3, s. 61-63. Książki I. Gulgowskiego reklamowano na łamach numeru siódmego „Vereinsnachrichten”. Von einem unbekannten Volke kosztowało $4 \mathrm{mk}$ za wydanie w oprawie oraz 3,50 za broszurę.

${ }^{81}$ Ernst SeEfrRIEd-Gulgowski, Ländlicher Hausfleiß in der Kaschubei, Berlin 1911 (wyd. 2: Berlin 1914); recenzje: Schweizerisches Archiv für Volkskunde, Jg. 16: 1912, s. 248-249; Stanisław KUJот, Zapiski TNT, t. 2: 1911, z. 4, s. 92-93.

${ }_{82}$ Artykuły lub sprawozdania ukazały się m.in. na łamach: Berliner Dienst z 2 II 1911 r.; Danziger Neueste Nachrichten, z 24 I 1911 r.; Deutsche Tageszeitung z 18 II 1911 r.; Neue Preußische Zeitung (Kreuzzeitung) z 20 II 1911 r.; Hamburger Nachrichten z 24 II 1911 r.

${ }^{83}$ Heinrich Sohnrey, Geleitwort, [in:] E. SeEfried-Gulgowski, Von einem unbekannten Volke, s. 7-19.

${ }^{84}$ H. Sohnrey osadnictwem w Wielkopolsce i Prusach Zachodnich zajął się już w 1897 r., zob. Heinrich SoHnrey, Eine Wanderfahrt durch die deutschen Ansiedlungsgebiete in Posen und Westpreußen, Berlin 1897.

${ }^{85}$ A. Bukowski pisze o wielokrotnych wizytach H. Sohnreya w Prusach Zachodnich, zob. A. BuKowsкi, Regionalizm kaszubski.

${ }^{86}$ J. Borzyszkowski, O Izydorze Gulgowskim, s. LVIII-LIX.

${ }^{87}$ Heinrich Sohnrey, Das Ansiedlungswesen in Posen und Westpreußen, Das Land, Jg. 5: 1896/1897, s. 116-118, 130-135, 148-149, 230-232, 277-282. 
cepcji to nie tylko zło, lecz i miejsce wykorzenienia społecznego. Jedynie zdrowe chłopstwo - lud - może w tej sytuacji zachować pierwiastek narodowy (Der Zug vom Lande, 1894) $)^{88}$. I. Gulgowski zaangażował się w powołanie do życia zachodniopruskiego koła kierowanej przez H. Sohnreya organizacji Deutscher Verein für ländliche Wolhlfahrts- und Heimatpflege i uczestniczył w zebraniu komitetu organizacyjnego w Gdańsku ${ }^{89}$. Spotkanie w hotelu Reichshof 25 I 1910 r., w którym wziął udział sam H. Sohnrey, zebrało wybitne grono przedstawicieli życia politycznego i władz prowincji, co dla I. Gulgowskiego, nauczyciela z Kaszub, musiało być silnym wsparciem dla jego działalności. I. Gulgowski, określony w relacji prasowej jako „verdienstvolle Wiedererwecker und Förderer der kassubische Volkskunst”, zabrał nawet głos w czasie obrad ${ }^{90}$. Wydarzenie zostało odnotowane na łamach „Gryfa”. Mimo uznania dla działalności H. Sohnreya młodokaszubski komentator nie miał złudzeń co do końcowych efektów działalności: „Już sam fakt, że na założenie oddziału zachodnio-pruskiego nie zaproszono nikogo z Polaków, daje dowód, jakim korytem ma płynąć dalsza działalność organizacji [...]"91. Nie wymieniając I. Gulgowskiego z nazwiska, odmówiono mu równocześnie, zresztą nie po raz pierwszy, polskości. On sam w roku następnym (1 III $1911 \mathrm{r}$.) w trakcie pierwszego zebrania walnego oddziału zachodniopruskiego przedstawił rezultaty prac na rzecz ożywienia tkactwa. Tekst referatu I. Gulgowskiego został zakończony pompatycznym wezwaniem: „Wie sagt doch unser wackerer Führer Heinrich Sohnrey: Stets habe vor Augen ein herrliches Ziel, Erreichst du nicht alles, erreichst du doch viel". Ten wykład podstawowych zamysłów społeczno-politycznych H. Sohnreya został opublikowany w 1911 r. w pierwszym zeszycie zachodniopruskiego oddziału organizacji ${ }^{92}$.

Wypowiedzi H. Sohnreya nie pozostały bez wpływu na działalność Towarzystwa w 1911 r. Wstęp poprzedzający książkę I. Gulgowskiego stanowił polityczną replikę na stanowisko Ostmarkenverein ${ }^{93}$ i zawiera pochwałę pracy małżeństwa I. i T. Gulgowskich. Równocześnie jednak zawierał personalną krytykę A. Majkowskiego i jego środowiska oraz F.W. Lorentza. Tego ostatniego za to, że publikuje na łamach „Gryfa”. Jak zauważył H. Sohnrey, F.W. Lorentz miał rzekomo przyznać, że to krok nierozważny: „Der Gryf hat im vorigen Jahrgang die Uebersetzung eines wissenschaftlichen Aufssatzes (aus dem Deutschen) [...] von Dr. Loretz veröffent-

${ }^{88}$ Zob. Reiner DrIEver, Heinrich Sohnrey (1859-1948), http://www.google.pl/url?url=http:// www.stadtarchiv.goettingen. de/strassennamen/Heinrich-Sohnrey.pdf\&rct $=\mathrm{j} \& \mathrm{q}=\& \mathrm{esrc}=\mathrm{s} \& \mathrm{sa}=\mathrm{U} \& \mathrm{e}$ $\mathrm{i}=\mathrm{o} \_$ndVLH8O8vkaq3og NAP\&ved=0CEIQFjAM\&usg=AFQjCNHuoSu008RuqIgqPkGnFbigU9A UMw (dostęp z 1 II 2015 r.).

${ }^{89}$ Zaproszenie na zebranie założycielskie: APGd., sygn. 361/125, s. 238 (lista członków założycieli, wśród nich również I. Gulgowski). Warto zaznaczyć, że I. Gulgowski obok tak wybitnych twórców kultury, jak m.in. Max Liebermann, Max Klinger czy Gerhard Hauptmann, należał w 1912 r. do zarządu wpływowego Dürerbund - Związku Dürerowskiego.

${ }^{90}$ Danziger Neueste Nachrichten, Nr. 21 z 26 I 1910 r. (wycinek: APGd., sygn. 361/129, s. 242).

${ }^{91}$ Kronika, Gryf, R. 2: 1910, nr 3, s. 96.

${ }^{92}$ Ernst Seefried-Gulgowski, Hausfleissboden in Westpreußen, Marienwerder 1911.

${ }^{93}$ A. Bukowski, Regionalizm kaszubski, s. 154-155. 
licht. Diese Mitarbeit am Gryf mußte, wie Dr. L[orentz] nun auch wohl selber einsehen hat, mit Recht befremden und Widerspruch erwecken. Auf so heißen Boden darf auch der rein wissenschaftliche Schriftsteller nicht so naiv oder gleichgultig jenseits der feindlichen Gewalten stehen"94.

Nawet jeśli F.W. Lorentz zrozumiał swoją rzekomą naiwność, to nie na tyle, by zerwać współpracę z „Gryfem”; jego prace ukazywały się w dalszym ciągu w czasopiśmie A. Majkowskiego. Mało tego, sam A. Majkowski w liście do siostry pisze: „[Gryf] właściwie redaguje Lorentz, ale musi pozostać z różnych powodów za kulisami" ${ }^{95}$. Pozostaje pytanie, jak stanowisko H. Sohnreya wpłynęło na współpracę F.W. Lorentza z I. Gulgowskim. Trudno tu o jednoznaczne oceny, lecz zapewne F.W. Lorentzowi nie przyszło łatwo pogodzić się z wypowiedziami, które opublikowano w pracy kolegi. W tym momencie możliwości dalszej współpracy założycieli Towarzystwa zostały wyczerpane, przynajmniej na pewien czas. O kłopotach i rocznym zawieszeniu aktywności poinformował członków biuletyn Towarzystwa: „Infolge innerer Vereinsangelegenheiten, die zuletzt einen Wechsel im Vorstand machten, musste jede andere Arbeit zurückgestellt werden" ${ }^{96}$. Z wewnętrznych opinii sporządzonych w styczniu 1914 r. do wiadomości władz prowincjonalnych wynika, że odejście F.W. Lorentza spowodowane było zdefraudowaniem przez niego części składek członkowskich. Kompromitującej sprawy nie nagłośniano, a F.W. Lorentz, który 10 października 1913 r. przeprowadził się do Oliwy, uregulował większość należności z honorariów autorskich: „Er hat aus der Vereinskasse für sich verwendten Beiträge bis auf eine ganz geringe Summe wieder zurückerstattet, da er seit mehrere Monaten für sich litterarische Arbeiten von der Akademie in Petersburg eine ständige Pränumeration beziehen soll"97.

Na zebraniu 11 XI 1911 r. przejęto rezygnację F.W. Lorentza, wybierając na to stanowisko jego dotychczasowego zastępcę, Polaka ks. A. Kopaczewskiego z Goręczyna. F.W. Lorentz pozostał członkiem Towarzystwa, publikował nadal w „Mitteilungen”, lecz wycofał się z jego współredagowania, poświęcając się dokończeniu własnych planów wydawniczych. Sytuacja nowego przewodniczącego nie należała do łatwych ${ }^{98}$. Dlatego w czasie obrad zwrócono uwagę na znaczenie zmienionego $\S 1$ statutu: „Der Verein versteht unter der kaschubischen Volkskunde im weitesten Sinne nicht nur die Volkskunde der Kaschuben, sondern die aller Zeiten un aller Stämme in der Kaschubei”. A. Kopaczewski przekazał członkom prośbę, by nie opuszczali organizacji: „Kopczinski [sic! - E.K.] richtete an die Versammlung die Bitte dem Verein treu zu bleiben”. Towarzystwo zdystansowało się od komentowania wypowiedzi H. Sohnreya, również tych sformułowanych w przedmowie

${ }^{94} \mathrm{H}$. SOHNREY, Geleitwort.

${ }^{95}$ Zob. Andrzej Buкоwsкi, Listy Aleksandra Majkowskiego do siostry Franciszki z lat 1910-1918, Rocznik Gdański, t. 51: 1991, z. 2, s. 164 (list 6 z 30 X 1911 r.).

${ }^{96}$ Vereinsnachrichten, Nr. 7, s. 3.

${ }^{97}$ APGd. sygn. 7/199, s. 564-565.

${ }^{98}$ Nota w rubryce „Vereine, Versammlungen” w: Danziger Neueste Nachrichten, Nr. 267 z 13 XI 1911 r., s. 10. 
do książki I. Gulgowskiego. W dodatku specjalnym do siódmego numeru „Vereinsnachrichten” zadeklarowano po raz kolejny: „Unser Verein ist ein unpolitischer Verein, Wir nehmen demgemäss für keine politische Richtung Partei und lehnen dashalb auch grundsätzlich jede Stellungnahme für oder wider die Sohnrey'sche Auffassung ab, indem wir auf $§ 1$ der Satzungen hinweisen"99.

Oburzeniem zareagowało na tekst H. Sohnreya środowisko Ostmarkenverein. Atak przeprowadzono w trakcie walnego zebrania członków hakatystów 13 III 1911 r. ${ }^{100}$ Wykład na temat kaszubszczyzny i ruchu młodokaszubskiego („Kaschubentum und die jungkaschubische Bewegung”) wygłosił pastor Harder z Kościerzyny. W omówieniu na łamach konserwatywnej „Danziger Allgemeine Zeitung”101 przytoczono główne wątki wystąpienia. Po wstępie historycznym mówca przeszedł do wydarzeń współczesnych i pracy I. Gulgowskiego, zapytując, czy wszystko, co I. Gulgowski odkrywa na Kaszubach, jest kaszubskie ${ }^{102}$. Czy w ogóle należy tego rodzaju działalność wspierać? Pytania nie były retoryczne, Harder udzielił na nie jednoznacznej odpowiedzi: „Alle Maßnahmen, kaschubisches Volkstum zu fördern, sind ein zweischneidiges Schwert”. Mówca skupił się na hafcie kaszubskim z Wdzydz, podkreślając brak zrozumienia dla tworzenia kultury, której Kaszubi nigdy nie mieli („Er hält es nicht für richtig, daß man die Kaschuben hier zu einer Kultur erzieht, die sie nie besessen haben"). Dalej Harder podziwiał genialne dzieło T. Gulgowskiej („Die unlegbare Genialität und der Fleiß der Frau Gulgowski sind anzuerkennen [...]”), równocześnie wydziwiając nad rzekomymi zgubnymi skutkami wysokich dochodów uzyskiwanych przez chłopskie dziewczyny ze sprzedaży haftów. Na zakończenie członkowie podjęli uchwałę, w której dano wyraz ubolewaniu i odrzucono nieuzasadnione ataki profesora H. Sohnreya pod adresem Ostmarkenverein. Wyrażono przekonanie, że inicjatywy Towarzystwa to działania na rzecz polskości i służą tylko Polakom: „Weiter wird zum Ausdruck gebracht, daß die Bestrebungen, das kaschubische Volkstum zu heben, nur den Polen zugute kommen und daß nur deutsche Kultur und deutsche Festigkeit die Möglichkeiten bieten die Kaschuben dem Deutschtum zu erhalten".

Izydor Gulgowski konsekwentnie milczał, lecz głęboko urażony H. Sohnrey nie pozostał dłużny i na łamach „Posener Zeitung”"103 ustosunkował się ponownie do ataków. Wymiana stanowisk przeciągała się, albowiem repliką na stanowisko

${ }^{99}$ Vereinsnachrichten, Nachtrag zu Nr. 7 [Karthaus 1911] (APGd., sygn. 361/129, s. 110). Sytuację środowisk polskich scharakteryzowano syntetycznie w: Szczepan WierzchosŁawski, Orzeł Czarny i Orzeł Biały. Problemy modernizacji społeczeństwa polskiego prowincji Prusy Zachodnie w XIX i na poczatku XX stulecia, Olsztyn 2011, s. 124-176.

${ }^{100}$ Druk zaproszenia z programem zebrania koła Ostmarkenverein: APGd., sygn. 361/125, s. 74.

${ }^{101}$ Die Ortsgruppe Danzig des Deutschen Ostmarkenvereins, Danziger Allgemeine Zeitung z 14 III 1911 r., s. 7.

102 „Gulgowski hat alles, was er bei den Kaschuben entdeckte, in gutem Glauben an ihre eigene Kultur aufgenommen. Das Lied, die Märchen usw. sind die aber als ausgesprochen Kaschubisch zu reklamieren? [...]" (ibid.).

${ }^{103}$ Omówienie w: Gazeta Gdańska, nr 39 z 1911 r. Cyt. za: A. Buкоwsкi, Regionalizm kaszubski, s. 155 , przyp. 65 . 
H. Sohnreya był krytyczny komentarz ogłoszony w „Danziger Zeitung”104. Autor podkreślił jednostronność źródeł informacji H. Sohnreya na temat Kaszubów (rzekomo jedynie rozmowy z I. Gulgowskim) i przedstawił niebezpieczny wzrost znaczenia lokalnych polskich organizacji gospodarczych. Po czym wskazał, że działalność, w tym również na rzecz kultywowania ludowej kultury kaszubskiej, w efekcie prowadzą jedynie do wzmocnienia polskości. Odnosząc się do tłumaczenia, że chodzi jedynie o działania naukowe, powtórzył wcześniejsze argumenty: „Daß das Motiv jener volkskundliche Arbeiten vielfach ein rein wissenschaftliche Interesse ist, erkennen wir volkommen an. Aber das ändert nicht auf die Motive, sondern auf die Wirkung an, und die ist, wie gesagt, unter allen Umständen nur dem Polentum nützlich". Stanowisko hakatystów było jasne: naukowa działalność ludoznawcza na Kaszubach, choćby prowadzona przez Niemców i po niemiecku, jedynie uzupełniała zjawisko polskiego odrodzenia narodowego. Apolityczny udział rodaków w tym przedsięwzięciu postrzegano jako działalność „użytecznych idiotów", którzy wspomagają polskośćc ${ }^{105}$.

Z kolei konflikt ten sprzyjał planom A. Majkowskiego i (współ)kierowanego przez niego ruchu młodokaszubskiego, który definiował się w opozycji wobec narodowo obojętnych celów Towarzystwa. W opublikowanej 3 VII 1912 r. w „Danziger Neueste Nachrichten” relacji z zebrania młodokaszubów podkreślono wypowiedź Majkowskiego ze zjazdu w Sopocie: „Der «Verein für kaschubischen Volkskunde» ist von Dr. Lorentz (einem deutschen Gelehrten, der als Mundartforscher tätig ist) und den Volksschullehrer Gulgowski begründet worden. Dem Verein, der anfangs lediglich wissenschaftliche Zwecke verfolgte, gehörten auch viele Polen an. Die traten später aus dem Verein aus und veranlaßten auch viele Kaschuben, sich ihnen anzuschließen. So entstand die jungkaschubische Bewegung die national-polnische Bestrebungen verfolgt"106.

Nie ulega wątpliwości, że A. Majkowski zebrał wokół siebie środowisko, które stopniowo radykalizowało swoje stanowisko. W pierwszym okresie ukazywania się "Gryfa", którego pierwszy numer wyszedł w listopadzie 1908 r., można czasopismo traktować jeszcze jako rodzaj polskojęzycznego uzupełnienia działalności F.W. Lorentza i I. Gulgowskiego. F.W. Lorentz z życzliwością recenzuje pierwsze zeszyty wydawane przez konkurencję, aczkolwiek nie bez pewnej uszczypliwości dotyczącej jakości edytorskiej, zżymając się też na błędy w pisowni kaszubskiej ${ }^{107}$. Wielokrotnie

${ }^{104}$ E. Z. [Ernst Zeнm?], Zuschriften an die Redaktion: Professor Sohnrey und die Kaschubentum, Danziger Zeitung, Jg. 53: 1911, Nr. 177 z 14 IV 1911 r.

${ }^{105}$ Stanowisko Deutscher Ostmarkenverein podsumowano w: Georg Cardinal von WidDERN, Polnische Eroberungszüge im heutigen Deutschland und deutsche Abwehr: In Westpreussen, Ostpreussen und Pommern, T. 1, Lissa 1913.

${ }^{106}$ W rubryce informacji lokalnych - „Lokales”: Die jungkaschubische Bewegung, Danziger Neueste Nachrichten, Nr. 19 z 1912 r., s. 2.

107 „Weniger gefallen mir die mitgeteilten Kaschubischen Texten, besonder wegen der durchaus unzulänglichen Ortographie”, „Das Papier der Monatsschrift ist gut, der Druck aber gerade zu schrecklich" (Mitteilungen, Bd. 1, s. 109-110). 
publikuje również w czasopiśmie A. Majkowskiego ${ }^{108}$. Z kolei na łamach „Gryfu”109 na ogół przychylnie recenzowano artykuły publikowane w organie Towarzystwa, doceniono również książkę I. Gulgowskiego ${ }^{110}$, choć wywoływała ona ambiwalentne odczucia $^{111}$. Z jeden strony dostrzegano wagę i doniosłość społeczną dzieła, również z punktu widzenia celów politycznych młodokaszubów. Z drugiej jednak A. Majkowski szydził, że „niemieckiemu nauczycielowi Gulgowskiemu” dostało się za to, „że u ludu kaszubskiego w Wdzydzach przez budzenie przemysłu ludowego pomaga wieśniakom do dobrobytu"112. W środowisku odczuwano satysfakcję ze stwierdzeń H. Sohnreya, traktując je jednak jako wyraz konfliktu wewnątrzniemieckiego, który powinien raczej satysfakcjonować, a nie martwić: albowiem „akcja jest pożarem w domu niemieckim, którego gasić najmniejszego nie mamy powodu"113.

Rozdźwięki w środowiskach niemieckich z subiektywnymi wyborami dyskusji publicystycznej publikowano z komentarzami na łamach „Gryfa”114. Równocześnie nie sposób nie dostrzec rozejścia się dróg Towarzystwa i politycznego środowiska młodokaszubów. Nie można mówić o otwartym konflikcie, lecz przypisywanie I. Gulgowskiego do ruchu młodokaszubskiego przed 1918/1920 r. jest co najmniej nadinterpretacją ${ }^{115}$. Nie ma na to dostatecznych dowodów $\mathrm{z}$ badanego okresu. Bez względu na wszelkie sympatie i antypatie I. Gulgowski, już choćby z tytułu funkcji pełnionej w zarządzie Towarzystwa, zachował dystans wobec ruchu młodokaszubskiego i jego twórców. W przeciwieństwie do swego kolegi F.W. Lorentza nie gościł na łamach ówczesnego "Gryfa”"116, nie publikował po polsku ${ }^{117}$, nie opuścił też

${ }^{108}$ Friedrich Lorentz, Obszar mowy kaszubskiej, Gryf, R. 1: 1910, nr 4, s. 97-101; idem, W sprawie pisowni kaszubskiej, ibid., R. 2: 1910, nr 3, s. 73-77; idem, Krytyczne uwagi do pisowni kaszubskiej, ibid., R. 3: 1911, nr 4-5, s. 117-118; idem, Zarys akcentuacyi pótnocno-kaszubskiej, ibid., R. 2: 1910, nr 3, s. 73-77. Zob. „Gryf” wraz z dodatkiem „Gryf pomorski” (1908-1934). Bibliografia zawartości, oprac. Krystyna KamińsKa, Gdańsk 1961.

${ }^{109}$ Verein für Kaschubische Volkskunde, Gryf, R. 3: 1911, nr 3, s. 91.

${ }^{110}$ Nota w rubryce „Książki i czasopisma”: Gryf, R. 3: 1911, nr 1-2, s. 27-28.

${ }^{111}$ W sprawie głośnego artykułu profesora Sohnreya, Gryf, R. 3: 1911, nr 3 s. 91-93; inne wypowiedzi zob. w: J. Borzyszkowski, O Izydorze Gulgowskim, s. LI, przyp. 36.

112 Zwycięstwo hakatyzmu nad nauką, Gryf, R. 2: 1910, nr 10, s. 293.

${ }^{113}$ Ibid., s. 289-294. Komentarz do zmian w statucie Towarzystwa na posiedzeniu 26 IX $1910 \mathrm{r}$.

114 Aleksander Majkowski, Prasa niemiecka a Kaszubi, Gryf, R. 3: 1911, nr 1-2, s. 15-17; nr 3, s. 82-83. Faksymile tekstów zob. w: J. Borzyszkowski, O Izydorze Gulgowskim, s. CXXVIII-CXXXV. Stanowiska innych gazet polskich zob. Andrzej Romanow, „Pielgrzym” pelpliński w latach 1869-1920, Gdańsk-Pelplin 2007, s. 206-207; idem, Problematyka kaszubska na łamach prasy polskiej w Gdańsku w latach 1891-1920, Acta Cassubiana, t. 1: 1999, s. 20-29.

${ }^{115}$ J. Borzyszkowski, Kaszubskie Towarzystwo Ludoznawcze, s. 12; biogramy I. Gulgowskiego i jego żony włączone zostały do zbioru: Józef Borzyszkowski, Cezary OBrachT-ProndzyŃski, Młodokaszubi. Szkice biograficzne, Gdańsk 2012.

${ }^{116}$ Po odnotowaniu na łamach „Gryfa” tekstu I. Gulgowskiego (Die Pflanzenwelt im kaschubischen Volksglauben, Das Land, Jg. 18: 1910, Nr. 22 redakcja zapowiedziała, „że postaramy się o pozwolenie autora na przetłumaczenie pracy w Gryfie”, zob. Gryf, R. 2: 1910, nr 11, s. 348. Tekst w „Gryfie” nie ukazał się. Dopiero w 1921 r. na łamach „Gryfa” ukazały się jego artykuły w języku polskim, zob. Gryf (wraz z dodatkiem Gryf Kaszubski), nr 18-19, s. 34.

${ }^{117}$ Wyjątkiem jest publikacja tłumaczenia starszego artykułu w krakowskim miesięczniku: Izydor Gulgowski, Domy drewniane Kaszubów, Architekt, R. 6: 1905, nr 12, s. 189-194. 
Towarzystwa, którego był współtwórcą. Dla I. Gulgowskiego (nauczyciela i organicznika) - zgodnie z myślą H. Sohnreya - ludoznawstwo i ludowe chałupnictwo było drogą do podniesienia kultury życia ludności chłopskiej, dla lokalnego polskiego polityka A. Majkowskiego to jedno z narzędzi walki o regionalne przebudzenie narodowe. Przytaczane w literaturze ciepłe wspomnienia A. Majkowskiego o I. i T. Gulgowskich opisują przede wszystkim stan umysłów z końca lat trzydziestych $^{118}$ i są odległe od napięć z przełomu pierwszych dekad XX w.

Wybuch wojny światowej doprowadził do zawieszenia owej próby nawiązania równoprawnej współpracy ludoznawców oraz regionalistów niemieckich i polskich, do jakiej doszło w Prusach Zachodnich ${ }^{119}$. Brak tu miejsca dla omówienia wielu wątków wyłaniających się z lektury źródeł dokumentujących działalność środowiska Verein für kaschubische Volkskunde. Licząc na konstruktywną dyskusję, w osobnych artykułach nawiążę do związków małżeństwa I. i T. Gulgowskich z H. Sohnreyem, jak również opiszę genezę ceramiki Franciszka Necla oraz dzieje wystawiennictwa ludowej sztuki kaszubskiej przed $1914 \mathrm{r}$.

prof. dr hab. Edmund Kizik

Instytut Historii PAN

e-mail: filcek@ug.gda.pl

${ }_{118}$ Np. J. BorzyszKowski, Aleksander Majkowski, s. 240-243.

${ }^{119}$ M. NiedZIELSKA, op.cit., s. 190. 
DER VEREIN FÜR KASCHUBISCHE VOLKSKUNDE IN DEN JAHREN 1907-1914. DIE KASCHUBISCHE VOLKSKUNDE ZWISCHEN DEUTSCHTUM UND POLENTUM

\section{Zusammenfassung}

Schlüsselbegriffe: Wissenschaftliche Gesellschaft, Volkskunde, Westpreußen, Kaschubien

Zu den interessantesten Episoden bei der Organisation des wissenschaftlichen Lebens in Westpreußen gehört der Verein für kaschubische Volkskunde, der vor dem Ausbruch des 1. Weltkriegs für mehrere Jahre tätig war. Diese östliche Provinz Deutschlands wurde von Polen, Deutschen und Kaschuben bewohnt. Die Kaschuben lebten vor allem in den ländlichen Regionen des Regierungsbezirks Danzig und gehörten zur ärmsten Bevölkerungsschicht. Ihr dem Polnischen nahestehender Dialekt und ihre Volkskultur hatten seit langem das Interesse der Volkskundler und Sprachwissenschaftler erregt. 1907 gründeten ein Pole, der Lehrer und Aktivist Izydor Gulgowski aus Wdzidze, auch als Ernst SeefriedGulgowski (1874-1925) bekannt, und ein Deutscher, der Sprachwissenschaftler Dr. Friedrich Lorentz (1870-1937) die Gesellschaft, in der sich sowohl Deutsche als auch Polen und ebenso einige Kaschuben zusammenfanden. Ziel war die Konzentration und Intensivierung der Forschungen zur Kultur der Kaschuben. Die Gesellschaft mit Sitz in Karthaus begann mit der Herausgabe einer eigenen wissenschaftlichen Zeitschrift, den „Mitteilungen des Vereins für kaschubische Volkskunde”, und trug zur Rettung von Überresten der Volkskultur bei. Doch in einer Zeit starker nationaler Spannungen und wachsender politischer Bestrebungen der Polen rief die Tätigkeit der Gesellschaft eine Reihe von politischen Kontroversen hervor. Nach Ansicht mancher deutscher Gruppen, vor allem solcher, die mit dem Ostmarkenverein verbunden waren, führte die Tätigkeit der Gesellschaft zu einer Stärkung des Polentums. Ein Teil der polnisch-kaschubischen politischen Aktivisten, wie z. B. Dr. Aleksander Majkowski, benutzte das Anwachsen der Aktivität und des Eigenbewusstseins unter den Kaschuben für die eigenen Ziele im politischen Kampf, indem er eine jungkaschubische Bewegung schuf (1912). Wissenschaftliche und volkskundliche Fragen waren nur Mittel bei der Realisierung von nationalen Zielen. Im Artikel werden auf der Grundlage von Quellen aus Archiven (Staatsarchiv in Danzig), Presse und Publizistik die Strukturen der Gesellschaft, die Finanzierungsquellen und die wissenschaftlichen Errungenschaften dargestellt. Der Autor analysiert die Gründe für die unterschiedlichen Einstellungen ihrer prominenten Mitglieder: Izydor Gulgowskis, eines gesellschaftlichen Aktivisten, der unter dem Einfluss des umstrittenen Denkens von Heinrich Sohnrey stand, des Wissenschaftlers Lorentz und des Politikers A. Majkowski. 
VEREIN FÜR KASCHUBISCHE VOLKSKUNDE IN THE YEARS 1907-1914. KASHUBIAN ETHNOGRAPHY BETWEEN THE GERMAN AND THE POLISH

\section{Summary}

Key words: scientific society, ethnography, West Prussia, Kashubia

Verein für kaschubische Volkskunde, which operated for several years prior to the outbreak of WW I, is one of the most interesting episodes in the organisation of scientific life in West Prussia. The eastern province of Germany was inhabited by Poles, Germans and Kashubians. Kashubians inhabited mainly the rural areas of the regency of Gdansk and belonged to the poorest social strata. Their dialect resembled the Polish language, while their folklore attracted the interest of ethnographers and linguists. In 1907 a Pole, a teacher and a social activist from Wdzydze - Izydor Gulgowski, also known as Ernts Seefried-Gulgowski (1874-1925), and a German linguist Dr Friedrich Lorentz (1870-1937) set up the Society whose members were Germans, Poles and a few Kashubians. Its aim was to integrate and intensify the research on the culture of Kashubia. The Society seated in Kartuzy started to issue their own scientific journal Mitteilungen des Vereins für kaschubische Volkskunde and it contributed to the preservation of the relics of folk culture. However, in the period of national tensions and the increase in political aspirations of Poles, the activity of the Society gave rise to many political controversies. According to some German circles, particularly the ones connected with Ostmarkenverein, the activity of the Society led to the strengthening of Polishness. Some Polish-Kashubian political activists such as Dr Aleksander Majkowski used the increase in the activity and awareness among Kashubians for their own political purposes creating the Society of Young Kashubians (1912). The scientific and ethnographic questions were only a tool to execute national objectives. The article presents the structure of the Society, the source of its financing, scientific achievements on the basis of archival sources (the State Archive in Gdansk), the press and journalism. The author analyses the reasons for different attitudes of its prominent members such as I. Gulgowski, a social activist influenced by the thinker Heinrich Sohnrey, the scientist Lorentz and the politician Aleksander Majkowski. 